\title{
KELOMPOK TANI PROGRAM INTENSIFIKASI SISTEM MINA PADI (INSISMINDI) ${ }^{1)}$
}

\author{
M. Zayin Sukri'2) dan Suwardi ${ }^{3)}$ \\ 1) Dibiayai oleh DIPA Politeknik Negeri Jember Nomor : 0698/PL17.2/PM/2014 \\ 2) dan ${ }^{3)}$ Jurusan Produksi Pertanian, Politeknik Negeri Jember
}

\begin{abstract}
ABSTRAK
Lahan sawah di samping ditanami padi, dapat dimanfaatkan menjadi tempat pemeliharaan ikan yaitu sistem mina padi, sehingga dapat meningkatkan pendapatan petani. Beberapa keuntungan sistem mina padi adalah selain menghasilkan padi,memperoleh keuntungan lain seperti menghasilkan ikan, hama penyakit padi menjadi berkurang, kesuburan tanah meningkat, meningkatkan keseimbangan dan perbaikan ekologi sebab hama padi merupakan pakan alami bagi ikan dan kotoran ikan merupakan pupuk alami bagi tanaman padi.

Sistem mina padi di areal persawahan masih jarang dijumpai, hal ini karena kurangnya informasi tentang sistem mina padi sehingga petani belum menerapkannya di lahan sawah. Berdasarkan kondisi di atas peran untuk mengubah pola pikir kelompok tani padi dari system monokultur ke INSISMINDI merupakan tantangan dan peluang untuk meningkatkan pendapatan petani khususnya kelompok tani mitra Rukun Tani dan Tani Makmur.

Dari kegiatan budidaya tanaman dengan intensifikasi sistem mina padi yang telah dilaksanakan dapat disimpulkan sebagai berikut: Budidaya tanaman dengan intensifikasi sistem mina padi, dapat meningkatkan produksi tanaman, karena sistem tanam mina padi ini memberikan manfaat antara lain: (a) Kesuburan tanah dapat ditingkatkan, (b) Pertumbuhan gulma dapat ditekan, (c) populasi hama dan penyakit tanaman padi dapat ditekan, (d) Perilaku ikan dalam mencari makanan dapat memperbaiki struktur tanah. Dengan sistem tanam mina padi maka efisiensi dan produktivitas lahan lebih meningkat, yaitu hasil panen lahan tanpa mina padi (monokultur) seluas $1000 \mathrm{~m} 2$ sebanyak $560 \mathrm{~kg}$ gabah kering sawah, dengan harga gabah Rp 4.000,-/kg, maka pendapatan Rp 2.240.000,- Hasil riil panen pada lahan mina padi seluas $1000 \mathrm{~m} 2$ sebanyak $440 \mathrm{~kg}$ gabah kering sawah atau 78,6\% dari hasil tanpa mina padi, dengan harga $\mathrm{Rp} 4000,-/ \mathrm{kg}$, maka pendapatan Rp 1.760.000,-. Sedangkan hasil ikan sebanyak 60 kg dengan harga Rp. 20.000,-/kg, maka pendapatan dari ikan Rp 1.200.000,. Jadi total pendapatan gabah dan ikan Rp 2.960.000,- atau meningkat 32\% dibandingkan dengan budidaya tanpa mina padi (monokultur).
\end{abstract}

Keyword: Intensifikasi, ikan, minapadi.

\section{PENDAHULUAN}

Laju pertumbuhan penduduk Indonesia selama periode 2000-2010 lebih tinggi dibanding periode 19902000 berturut-turut sebesar 1,49 persen dan 1,45 persen, jumlah penduduk Indonesia tahun 2010 sebanyak 237,56 juta orang (Badan Pusat Statistik, 2010). Untuk memenuhi kebutuhan pangan 237,56 juta orang dibutuhkan lahan produktif untuk tanaman padi seluas 13 juta ha, namun hingga saat ini lahan padi yang diolah seluas 7,7 ha (Seafast, 2012).

Pertambahan penduduk sebesar $1,49 \%$ akan mendatangkan masalahmasalah sosial seperti kemiskinan, kelaparan, kekumuhan kota, berkurangnya daya dukung lahan dan masalah-masalah sosial lainnya. Di lain pihak kondisi lahan sawah yang subur sebagai sumber daya lahan utama produksi beras semakin lama semakin 
berkurang, dikarenakan adanya pergeseran fungsilahan ke non pertanian. Untuk mengatasi hal itu perlu dilakukan usaha pendayagunaan lahan yang ada melalui intensifikasi (Supriadiputra dan Setiawan,2005).

Lahan sawah dapat dimanfaatkan menjadi tempat pemeliharaan ikan sehingga pendapatan petani meningkatkan. Beberapa keuntungan sistem mina padi adalah selain menghasilkan padi,memperoleh keuntungan lain seperti menghasilkan ikan, hama penyakit padi menjadi berkurang, kesuburan tanah meningkat, meningkatkan keseimbangan dan perbaikan ekologi sebab hama padi merupakan pakan alami bagi ikan dan kotoran ikan merupakan pupuk alami bagi tanaman padi. Adanya simbiosis mutualisme padi dan ikan mendukung ketersediaan pangan dan perbaikan lingkungan sekaligus (Supriadiputra dan Setiawan, 2005).

Kabupaten Jember sebagai salah lumbung padi di Jawa Timur mempunyai luas areal pertanaman padi sebesar 155.126 Ha dengan produksi 830.000 ton. Salah satu kecamatan penghasil padi di Kabupaten Jember adalah Kecamatan Sumbersari dengan luasan 3.420 ha dengan produktivitas 5,102 ton/ha sehingga total produksi sebesar 17.449 ton.

Upaya meningkatkan pendapatan petani melalui INSISMINDI sangat cocok diterapkan dikarenakan kepemilikan lahan sawah per kapita yang relatif kecil. Perubahan strategi dari monokultur menjadi INSISMINDI diharapkan dapat memenuhi kebutuhan pangan dan meningkatkan pendapatan petani. Sistem budi daya ikan di sawah merupakan salah satu sistem yang praktis untuk meningkatkan efisiensi penggunaan lahan pada areal pertanaman padi sawah yang sempit.

Jika luas sawah yang digunakan $1.000 \mathrm{~m}^{2}$ dengan sistem penanaman mina padi, ikan yang ditebarkan setelah padi berumur 5-7 hari dengan ukuran bibit 5-8 cm sebanyak 1.000 ekor. Lama pemeliharaan ikan sampai pembungaan padi 75 hari dengan harga per kg ikan mencapai Rp. 20.000,-. Maka didapat perhitungan biaya, penerimaan dan keuntungan tertera pada Tabel 1.

Tabel 1. Perhitungan biaya, penerimaan dan keuntungan dari mina padi

\begin{tabular}{|c|c|c|}
\hline Uraian & $\begin{array}{c}\text { Harga } \\
\text { satuan } \\
\text { (Rp) }\end{array}$ & $\begin{array}{l}\text { Jumlah } \\
\text { (Rp) }\end{array}$ \\
\hline $\begin{array}{l}\text { A. Biaya: } \\
\text { 1. Benih ikan } 5-8 \mathrm{~cm} \\
(1.000 \text { ekor }) \\
\text { 2. Pakan: } \\
\text { - konsentrat ( } 35 \mathrm{~kg}) \\
\text { - dedak/bekatul }(70 \\
\text { kg) } \\
\text { - kotoran ayam ( } 200 \\
\text { kg) } \\
\text { 3. Tenaga kerja buat } \\
\text { parit }\end{array}$ & $\begin{array}{r}200,- \\
4000,- \\
1000,- \\
100,-\end{array}$ & $\begin{array}{r}200.000,- \\
140.000,- \\
70.000,- \\
20.000,- \\
250.000,-\end{array}$ \\
\hline Total pengeluaran & & $680.000,-$ \\
\hline $\begin{array}{l}\text { B. Penerimaan: } \\
\text { Hasil panen ikan (75 } \\
\text { kg) }\end{array}$ & 20.000, & 1.500.000,- \\
\hline C. Keuntungan & & $820.000,-$ \\
\hline
\end{tabular}

\section{Permasalahan Mitra}

Pemanfaatan lahan sawah untuk pertanaman padi dan tempat pemeliharaan ikan merupakan solusi untuk meningkatkan pendapatan petani karena keduanya bersifat komplementer, tanpa mengganggu keberhasilan satu sama lain sehingga pada akhirnya diperoleh hasil yang optimal (Khairuman dan Amri, 2002).

Sistem mina padi sangat efisien dalam penggunaan lahan, namun aplikasinya masih jarang ditemukan. Hal ini dikarenakan dalam penerapannya membutuhkan pendidikan dan pelatihan tentang teknik budi daya ikan dalam sawah.

Secara umum permasalahan yang ditemui di lapangan sebagai berikut:

1. Kelompok tani membutuhkan contoh demplot sistem mina padi sebelum mereka mengadopsi sistem INSISMINDI, hal ini dikarenakan adanya rasa ketidakpercayaan 
sebagian besar anggota kelompok tani.

2. Pola pikir sebagian besar anggota kelompok tani yang susah diubah dari sistem monokultur menjadi polikululur mina padi, hal ini menyangkut tingkat pendidikan yang mempengaruhi cara pandang mereka terhadap inovasi baru.

3. Petani mudah puas dengan hasil panen padi sehingga kurang termotivasi untuk meningkatkan pendapatan dengan menerapkan INSISMINDI.

4. Kepemilikan lahan yang sempit dan ketersediaan air yang cukup melimpah merupakan factor pendukung untuk menerapkan INSISMINDI di kalangan anggota kelompok tani.

5. Kesan yang ditangkap bahwa kelompok tani adalah mereka membutuhkan bukti untuk dapat menerapkan sistem INSISMINDI.

6. Adanya dukungan dari Dinas Pertanian untuk menerapkan INSISMINDI di tingkat kelompok tani.

Justifikasi dalam
$\begin{aligned} & \text { persoalan prioritas } \\ & \text { diselesaikan }\end{aligned}$
Keberhasilan program Intensifikasi Sistem Mina Padi (INSISMINDI) membutuhkan dukungan dari pihak-pihak terkait yaitu pelaksana (Politeknik Negeri Jember), Kelompok tani dan Dinas Pertanian Kabupaten Jember, dengan berkomitmen melakukan kesepakatan sebagai berikut:

1. Pihak Politeknik Negeri Jember

a) Memberikan penyuluhan tentang potensi pertanian padi yang menerapkan sistem mina padi dengan cara konvensional, sehingga secara ekonomi terlihat keuntungan dan kelebihan sistem mina padi.

b) Memberikan pelatihan kepada petani yang tergabung dalam dua kelompok tani "Rukun Makmur" dan "Tani Makmur"dengan membuat demplot mina padi berukuran $1.000 \mathrm{~m}^{2}$ sebanyak 2 buah. Pembuatan demplot melibatkan kelompok tani mitra dan Penyuluh dari Dinas Pertanian.

c) Seluruh biaya sewa lahan, pembuatan petakan mina padi, benih padi, benih ikan dan lain-lain menjadi tanggungan program IbM.

d) Hasil panen baik padi maupun ikan yang diperoleh dari demplot digunakan sepenuhnya sebagai modal awal bagi program INSISMINDI sehingga semakin banyak petani yang menerapkembangkan sistem ini.

2. Pihak Kelompok Tani "Rukun Makmur" dan "Tani Makmur".

a) Kelompok tani berkewajiban untuk merawat dan memelihara demplot.

b) Kelompok tani berkewajiban menerapkembangkan sistem INSISMINDI yang telah teruji keberhasilannya kepada anggota kelompok.

c) Kelompok Tani "Rukun Makmur" dan "Tani Makmur" bersedia menerima mahasiswa Politeknik Negeri Jember untuk kegiatan penelitian maupun Praktek Kerja Lapang.

\section{TARGET DAN LUARAN}

\section{Target dari kegiatan ini adalah:}

1. Adanya kesepakatan antara pelaksana dengan Dinas Pertanian (Penyuluh) untuk bersama-sama mengawal program INSISMINDI di tingkat kelompok tani mitra.

2. Kelompok tani mitra mempunyai pengetahuan, keterampilan dan kesadaran tentang manfaat INSISMINDI serta dengan kemauan dan kesadaran sendiri mau menerapkan program INSISMINDI.

3. Paling tidak terdapat 10 orang petani yang menerapkan INSISMINDI pada masing-masing kelompok tani pasca program dengan tetap dipantau dan diawasi 
oleh pelaksana program dan dinas terkait.

\section{Luaran dari kegiatan IbM ini adalah:}

1. Meningkatkan pendapatan petani. Petani akan mendapatkan tambahan penghasilan berupa ikan tanpa terkurangi pendapatannya dari tanaman padi serta mampu memenuhi kebutuhan protein hewani.

2. Meningkatkan produksi tanaman padi. Sistem ini akan memberikan manfaat antara lain: (a) Kesuburan tanah dapat ditingkatkan karena kotoran ikan dan sisa makanan berfungsi sebagai pupuk, (b) Pertumbuhan gulma dapat ditekan karena ikan memakan tumbuhtumbuhan kecil (gulma) yang tumbuh di sawah. Dengan demikian, persaingan antara padi dan gulma dalam mengisap makanan dapat dikurangi, (c) Perkembangan populasi hama dan penyakit tanaman padi dapat ditekan karena ikan memakan binatang-binatang kecil yang merupakan hama padi, (d) Perilaku ikan (terutama ikan mas) dalam mencari makanan bisanya dengan cara membolakbalik tanah. Hal ini dapat memperbaiki struktur tanah.

3. Tanaman padi menjadi lebih terkontrol karena si petani menjadi lebih sering pergi ke sawah. Akibatnya, pertumbuhan tanaman padi dan ikan menjadi lebih terawasi sehingga produknya lebih meningkat.

4. Meningkatkan efisiensi dan produktivitas lahan.

\section{METODE PELAKSANAAN}

Keragaman budidaya sistem mina padi melalui tahapan-tahapan sebagai berikut: (a) pengolahan tanah sistem mina padi, (b) penanaman padi, (c) penyulaman(d) penebaran benih ikan, (e) pemeliharaan ikan, (f) pemanenan ikan, $(\mathrm{g})$ penyiangan, $(\mathrm{h})$ pemupukan, $(\mathrm{i})$ pengairan (pemeliharaan padi), (j) pengendalian hama dan penyakit, (k) pemanenan, (k) perawatan hasil dan (l) penggilingan (Handoyo FL. 1989).

\section{Pengolahan Tanah}

Pengolahan tanah untuk budi daya ikan di sawah berbeda-beda, tergantung sistem pembudidayaannya. Pengolahan tanah untuk mina padi berbeda dengan sistem penyelang maupun palawija. Pengolahan tanah dalam mina padi sekaligus berfungsi ganda. Selain untuk persiapan tumbuhnya padi, pengolahan tanah juga memungkinkan tumbuhnya mikroorganisme sebagai makanan ikan.

\section{Pengolahan Tanah Sistem Mina Padi}

Pengolahan tanah berfungsi untuk menyediakan media yang baik bagi pertumbuhan tanaman padi maupun organisme lainnya. Kedalaman tanah berkisar antara $15-20 \mathrm{~cm}$. Pengolahan tanah dikatakan sempurna apabila perbandingan antara lumpur dengan air $=1: 1$. Kondisi ini dapat dicirikan dengan tidak menempelnya tanah apabila sebuah logam antikarat dicelupkan ke dalam lumpur kemudian diangkat. Apabila pengolahan tidak sempurna, maka pertumbuhan tanaman padi menjadi terganggu (Sudirman dan Ade Irawan, 1999).

Pada saat pengolahan tanah, juga diberikan pupuk yang berfungsi sebagai pupuk dasar. Pupuk yang biasa digunakan adalah pupuk $\mathrm{P}$ dan $\mathrm{K}$, sedangkan pupuk $\mathrm{N}$ diberikan 1/3 dari dosis yang diperlukan selama musim tanam. Selain pupuk, pada pengolahan tanah juga diberikan insektisida. Insektisida yang digunakan adalah insektisida organik untuk mengendalikan hama penggerek padi.

\section{Penanaman Padi}

Pada sistem mina padi di sawah, tanaman padi merupakan tanaman pokok, sehingga dalam pemeliharaannya tidak mengakibatkan munurunnya produk padi. Tanaman padi harus mendapatkan perhatian yang seksama 
agar pertumbuhannya sesuai dengan yang diharapkan. Padi yang ditanam sebaiknya dipilih yang cocok dengan lahan mina padi, seperti: perakaran dalam, cepat beranak, batang kuat dan tidak cepat rebah, ketinggian tanaman sedang, tahan genangan pada awal pertumbuhan, daun tegak, tahan hama dan penyakit, produksi tinggi serta rasanya enak sehingga disukai masyarakat.

Dengan memiliki sifat-sifat yang dikehendaki dalam sistem mina padi, maka tanaman padi yang dianjurkan untuk ditanam pada areal mina padi antara lain: IR 64, Ciliwung, Citanduy, Dodokan, Ciherang dan Cisadane.

\section{Penebaran Benih Ikan}

a. Pemilihan jenis ikan

Hampir semua jenis ikan dapat dipelihara dengan sistem budidaya ikan di sawah.Namun ada beberapa jenis ikan tertentu yang lebih menguntungkan dibandingkan jenis ikan lainnya. Jenis ikan yang banyak digunakan pada sistem mina padi adalah ikan tawes dan ikan mas, hal ini disebabkan kedua jenis ikan ini mampu hidup dengan baik di air yang dangkal, tahan panas, pertumbuhan cepat serta tidak mengganggu tanaman padi. Strain jenis Majalaya dari ikan mas ternyata saat ini merupakan jenis ikan yang banyak digunakan dalam sistem mina padi, dikarenakan lebih responsif dan pertumbuhannya cepat sehingga lebih menguntungkan (Ardiwinata, 1981).

Selain ikan mas dan tawes, jenis ikan lain yang juga baik dibudidayakan dengan sistem mina padi adalah ikan tambakan, mujair, nila dam nilem.

b. Cara memperoleh benih ikan.

Benih ikan yang akan ditebarkan merupakan salah satu faktor yang berpengaruh terhadap keberhasilan budi daya ikan di sawah. Benih ikan yang dipilih sebaiknya yang gesit, lincah, matanya bening, kulit terang dan berkilau. c. Kepadatan ikan

Kepadatan penebaran benih ikan di sawah bermacam-macam tergantung pada ketersediaan lahan, ukuran benih ikan pada saat ikan dipanen serta kelakuan atau adaptasi terhadap lingkungan.

Kepadatan ikan untuk sistem mina padi ditunjukkan pada Tabel 2.

Tabel 2. Kepadatan penebaran benih ikan pada sistem mina padi.

\begin{tabular}{|l|l|l|}
\hline $\begin{array}{l}\text { Ukura } \\
\text { n (cm) }\end{array}$ & $\begin{array}{l}\text { Berat } \\
\text { (g/ekor) }\end{array}$ & $\begin{array}{l}\text { Kepadatan } \\
\text { (ekor/ha) }\end{array}$ \\
\hline $1-3$ & $0,5-1,0$ & 100.000 \\
$3-5$ & $3,0-5,0$ & 120.000 \\
$5-8$ & $8,0-10,0$ & $50.000-60.000$ \\
$8-12$ & $20,0-25,0$ & $10.000-12.000$ \\
$>12$ & $>25,0$ & $2.500-3.000$ \\
& & $2.000-2.500$ \\
\hline
\end{tabular}

Sumber: Sadele, S.et al. (1989)

d. Penebaran benih ikan

Penebaran benih ikan dilakukan 5-7 hari setelah penanaman padi. Hal ini dimaksudkan untuk mengurangi resiko keracunan akibat penggunaan obatobatan atau pupuk yang digunakan pada waktu pengolahan tanah. Selain itu agar tanaman padi lebih kuat dahulu digenangi air. Ketinggian air pada waktu penebaran benih tergantung pada ukuran ikan yang akan ditebarkan. Semakin besar ukuran ikan semakin tinggi permukaan air yang diperlukan. Namun, permukaan air yang terlalu tinggi dapat mempengaruhi pertumbuhan tanaman padi. Untuk itu, ketinggian permukaan air yang umum dilakukan adalah 4-6 cm.

\section{Pemeliharaan Padi}

Pemeliharaan padi sistem mina padi harus diimbangi dengan pengetahuan tentang padi dan ikan supaya tidak menimbulkan kerugian pada ikan. Apabila pertumbuhan padi tidak normal, misalnya jumlah anakan kurang, maka dapat dilakukan dengan menurunkan 
permukaan air selama kurang lebih 3-4 hari.

Pemeliharaan padi meliputi pemupukan, pengendalian hama padi, pengendalian penyakit padi, pengendalian gulma dan tanaman pengganggu.

\section{Pemeliharaan ikan}

Agar ikan yang dihasilkan sesuai dengan yang diharapkan, pemeliharaan harus dilakukan secara benar.

\section{Pemberian pakan tambahan}

Pakan tambahan yang digunakan sebaiknya yang mudah didapat, murah, dan tidak membahayakan pertumbuhan dan perkembangan ikan maupun padi. Pakan yang umum digunakan pada sistem ini adalah dedak halus, ampas tahu, ampas kelapa, kotoran ayam, pupuk hijau, atau sisa makanan (dapur).Pemilihan pakan disesuaikan dengan ukuran ikan dan jenisnya Semakin kecil ukuran ikan, tekstur pakan yang diberikan semakin halus.

\section{HASIL DAN PEMBAHASAN}

Kegiatan budidaya tanaman dengan intensifikasi sistem mina padi yang telah dilaksanakan sampai saat ini adalah meliputi:

1. Pembuatan pesemaian, diawali dengan pengolahan tanah yang dilakukan kurang lebih 21 hari sebelum tanam. Tanah diairi, dibajak, dicangkul dan diinjak-injak sehingga menjadi lumpur kemudian diratakan, bedengan dibuat dengan ukuran 1,25 x $10 \mathrm{~m}$ dan tinggi $0,2 \mathrm{~m}$, sebanyak 10 bedeng. Benih yang digunakan varietas IR 64 sebanyak $40 \mathrm{~kg} / \mathrm{ha}$ atau $50 \mathrm{gr} / \mathrm{bedeng}$.

2. Pengolahan lahan sawah, sebelum tanah diolah dilakukan penggenangan selama 2 hari. Pengolahan tanah pertama dilakukan dengan cara tanah dibajak dengan handtraktor yaitu tanah dibalik, kemudian dihancurkan dan diratakan.
3. Pembuatan parit untuk pemeliharaan ikan. Setelah sekitar 3 hari tanah diolah kemudian dibuat parit keliling dan menyilang lahan, dengan ukuran kolam lebar 0,75 $\mathrm{m}$ dan panjang $35 \mathrm{~m}$ ( 2 buah), lebar $0,75 \mathrm{~m}$ dan panjang 10 m ( 6 buah), sehingga luas kolam ikan sekitar $100 \mathrm{~m} 2$ dan kedalaman 0,5 m.

4. Penanaman, dilakukan pada saat bibit berumur 21 hari sebanyak 2 bibit per lubang tanam, dengan sistem tanam jajar legowo 4: 1, yaitu jarak dalam baris $20 \mathrm{~cm}$, jarak antar baris $20 \mathrm{~cm}$, kemudian jarak antar 4 baris yang satu dengan 4 baris yang lainnya 40 $\mathrm{cm}$.

5. Penyebaran ikan, dilakukan 21 hari setelah tanam, sebanyak 2000 ekor per $100 \mathrm{~m} 2$ kolam dalam $1000 \mathrm{~m} 2$, ukuran ikan rata-rata $\pm 7 \mathrm{~cm}$.

6. Pemupukan dasar, dilakukan dengan menggunakan pupuk Urea sebanyak $100 \mathrm{~kg} / \mathrm{ha}$, TSP $100 \mathrm{~kg} / \mathrm{ha}$ dan KCl $100 \mathrm{~kg} / \mathrm{ha}$, dilakukan 1 hari sebelum tanam.

7. Pemupukan susulan dengan menggunakan pupuk urea, dilakukan 2 kali, pertama pada umur 3 dan kedua akan dilakukan umur 6 minggu setelah tanam, masing-masing 100 $\mathrm{kg} / \mathrm{ha}$.

8. Penyiangan, dilakukan 2 kali yaitu pertama pada umur 3 dan kedua akan dilakukan lagi pada umur 6 minggu setelah tanam dengan cara mencabut rumput dan membenamkannya ke dalam tanah.

9. Pengairan, dengan cara menggenangi lahan pertanaman selama pertumbuhan sampai satu minggu menjelang panen.

10. Pengendalian hama dan penyakit, dilakukan apabila terdapat gejala serangan hama/penyakit dengan menggunakan insektisida organik.

11. Pengamatan rata-rata jumlah malai sebanyak 16,8 malai per rumpun tanaman.

12. Hasil panen lahan tanpa mina padi (monokultur) seluas $1000 \mathrm{~m} 2$ sebanyak $560 \mathrm{~kg}$ gabah kering sawah, dengan harga gabah Rp 
4.000,-/kg, maka pendapatan $\mathrm{Rp}$ 2.240 .000 ,-

13. Hasil riil panen pada lahan mina padi seluas $1000 \mathrm{~m} 2$ sebanyak $440 \mathrm{~kg}$ gabah kering sawah atau 78,6 \% dari hasil tanpa mina padi, dengan harga Rp 4000,-/kg, maka pendapatan Rp 1.760.000,-. Sedangkan hasil ikan sebanyak $60 \mathrm{~kg}$ dengan harga $\mathrm{Rp}$. $20.000,-/ \mathrm{kg}$, maka pendapatan dari ikan Rp 1.200.000,-.

14. Jadi total pendapatan gabah dan ikan Rp 2.960.000,- atau meningkat 32\% dibandingkan dengan budidaya tanpa mina padi (monokultur).

\section{KESIMPULAN DAN SARAN}

\section{Kesimpulan}

Dari kegiatan budidaya tanaman dengan intensifikasi sistem mina padi yang telah dilaksanakan sampai saat ini dapat disimpulkan sebagi berikut:

1. Budidaya tanaman dengan intensifikasi sistem mina padi, dapat meningkatkan produksi tanaman, karena sistem tanam mina padi ini memberikan manfaat antara lain: (a) Kesuburan tanah dapat ditingkatkan, (b) Pertumbuhan gulma dapat ditekan, (c) populasi hama dan penyakit tanaman padi dapat ditekan, (d) Perilaku ikan dalam mencari makanan dapat memperbaiki struktur tanah.

2. Dengan sistem tanam mina padi maka efisiensi dan produktivitas lahan lebih meningkat, yaitu hasil panen lahan tanpa mina padi (monokultur) seluas $1000 \mathrm{~m} 2$ sebanyak $560 \mathrm{~kg}$ gabah kering sawah, dengan harga gabah $\mathrm{Rp}$ $4.000,-/ \mathrm{kg}$, maka pendapatan $\mathrm{Rp}$ 2.240.000,-

3. Hasil riil panen pada lahan mina padi seluas $1000 \mathrm{~m} 2$ sebanyak $440 \mathrm{~kg}$ gabah kering sawah atau 78,6 \% dari hasil tanpa mina padi, dengan harga Rp 4000,-/kg, maka pendapatan $\mathrm{Rp}$ 1.760.000,-. Sedangkan hasil ikan sebanyak $60 \mathrm{~kg}$ dengan harga $\mathrm{Rp}$. $20.000,-/ \mathrm{kg}$, maka pendapatan dari ikan Rp 1.200.000,-.
4. Jadi total pendapatan gabah dan ikan Rp 2.960.000,- atau meningkat 32\% dibandingkan dengan budidaya tanpa mina padi.

\section{Saran}

Dalam sistem mina padi sebaiknya dibudidayakan pada musim penghujan karena air cukup tersedia, sedangkan kalau pada musim kemarau air sangat terbatas.

\section{DAFTAR PUSTAKA}

Ardiwinata, R.0,. 1981. Pemeliharaan Ikan Mas di Sawah. Penerbit Sumur Bandung. Bandung

Handoyo FL. 1989. Mina-Padi.Penerbit CV Simplex. Jakarta.

Sadele S et al,. 1989. Petunjuk Teknis Sistem Usahatani Padi-Ikan. Balai Penelitian Tanaman Pangan Sukamandi. Sukamandi.

Asnawi, 1983, Badan Pusat Statistik. 2010. Statistik Indonesia (Statistical Yearbook of Indonesia). Jakarta

Barniati Anis. 2007. Analisis Finansial Usaha Mina Padi pada Kelompok TaniRukun Tani Mukti, Desa Arjasari, Kecamatan Leuwisari, KabupatenTasikmalaya.

Skripsi.Program Studi Manajemen Bisnis dan EkonomiPerikananKelautan.Fakultas Perikanan dan Ilmu Kelautan, IPB.

Khairuman, dan Amri K. 2002.Budi Daya Ikan di Sawah. PT Penebar Swadaya, Jakarta.

Sudirman dan Ade Iwan Setiawan. 2005. Mina padi (Budi Daya Ikan Bersama Padi). Penebar Swadaya, Jakarta.

Supriadiputra S. 1990. Variasi Padat Penebar Benih Ikan dengan dan Tanpa Pemupukan NPK pada Sistem Mina Padi. Skripsi. Fakultas Pertanian. Unsoed. 